\title{
Literasi Aspek Pemasaran pada UKM “Nabil Collection"
}

\section{Benny Diah Madusari ${ }^{1}$, Arum Ardianingsih ${ }^{2 *}$, Dwi Edi Wibowo ${ }^{3}$}

${ }^{1}$ Program Studi Budidaya Perikanan, Universitas Pekalongan, Jl. Sriwijaya no.03, Bendan, Kabupaten Pekalongan, Jawa Tengah, Indonesia, 51119.

${ }^{2}$ Program Studi Akuntansi, Universitas Pekalongan, Jl. Sriwijaya no.03, Bendan, Kabupaten Pekalongan, Jawa Tengah, Indonesia, 51119.

${ }^{3}$ Program Studi Hukum, Universitas Pekalongan, Jl. Sriwijaya no.03, Bendan, Kabupaten Pekalongan, Jawa Tengah, Indonesia, 51119.

*Email koresponden: arumbundavina@gmail.com

\section{ARTICLE INFO}

Article history

Received: 03 Okt 2021

Accepted: 08 Des 2021

Published: 31 Des 2021

\section{Kata kunci:}

Merk Dagang;

Pemasaran;

Sosial Media;

UKM;

\section{Keyword: \\ Marketing; \\ SME; \\ Social Media; \\ Trademark;}

\begin{abstract}
A B S T R A K
Background: UKM "Nabil Collection" merupakan UKM yang terdampak akibat pembatasan aktifitas diluar rumah. UKM "Nabil Collection" selama ini menjual produk pakaian berupa kemeja secara konvensional sehingga ketika ada kebijakan pembatasan aktifitas diluar rumah penjualan produknya menjadi menurun. Literasi ini dilakukan agar UKM "Nabil Collection" memiliki kemampuan untuk melakukan pengemasan produk, pentingnya merk dagang dan memilih media pemasaran secara tepat sesuai dengan sasaran pasar produk. Metode: Literasi kepada pemilik UKM" Nabil Collection" dengan memberikan modul aspek-aspek pemasaran produk kemeja. Hasil: Peningkatan pengetahuan pemilik UKM" Nabil Collection" tentang pengemasan produk, merk dagang, dan media pemasaran secara online dengan sosial media. Kesimpulan: Literasi aspek pemasaran ini menambah pengetahuan pemilik UKM" Nabil Collection" mengetahui pengemasan produk yang lebih kreatif, menyadari pentingnya merk dagang, harga produk kemeja lebih bersaing dan mencoba alternatif media pemasaran berbasis sosial media untuk meningkatkan penjualan produk dimasa pembatasan aktifitas diluar rumah.
\end{abstract}

\section{A B S T R A C T}

Background: "Nabil Collection" are SMEs affected by restrictions on activities outside the home. SME "Nabil Collection" has been selling its shirt products conventionally so that when there is a policy of limiting activities outside the home, the sales of their products decrease. This literacy is carried out so that the SME "Nabil Collection" has the ability to do product packaging, the importance of trademarks and choose the right marketing media according to the product market target. Method: Literacy for SME owners "Nabil Collection" by providing modules on the marketing aspects of shirt products. Result: increased knowledge of "Nabil Collection" SME owners about product packaging, trademarks and online marketing media with social media. Conclusions: This literacy aspect of marketing increases the knowledge of "Nabil Collection" SME owners knowing more creative product packaging, realizing the importance of trademarks, more competitive shirt product prices and trying alternative social media-based marketing media to increase product sales during the time of restrictions on activities outside the home.

\section{PENDAHULUAN}

Pelaku usaha kecil menengah (UKM) membantu membuka lapangan kerja dan menyerap tenaga kerja serta memberikan sumber penghidupan bagi masyarakat sebagai gerakan ekonomi kerakyatan. Secara umum, usaha kecil menengah (UKM) tidak memisahkan kekayaan usaha dan kekayaan pemilik. Menurut Mardiatmi \& Pinem, (2020) UMKM mampu menyerap tenaga kerja 
lebih dari setengah penyerapan daripada perusahaan besar. Hasil observasi tim atas aktifitas pelaku usaha kecil menengah (UKM) di Pekalongan maka pemasaran produk dari UKM lebih banyak dilakukan secara konvensional atau face to face dengan pembeli/konsumen baik partai besar/grosir atau ecer. Dinas perindustrian, koperasi dan UKM mencatat jumlah pelaku usaha binaanya sekitar 21.791 pelaku usaha mikro kecil dan menengah di Kota Pekalongan (BPS, 2020). Darwanto, (2013) dalam merekomendasikan bahwa agar berdaya saing maka pelaku UMKM harus memiliki daya inovasi dan kreativitas sehingga mampu bertahan dalam berbagai kondisi ekonomi serta bertahan dalam jangka Panjang. Inovasi dan kreatifitas dibutuhkan oleh pelaku UKM dalam aspek pemasaran seperti variasi produk, kemasan produk, pemilihan bahan baku, merk yang menarik, harga terjangkau dan memilih media pemasaran yang tepat.

Pekalongan sebagai kota batik juga dikenal sebagai basis industri rumahan seperti produksi kemeja, celana jeans yang kualitasnya dapat dibandingkan dengan konveksi pabrik. Industri rumahan mampu menyerap tenaga kerja sekitar lima sampai tujuh tenaga kerja. Industri rumahan merupakan bagian UKM yang memberikan kontribusi terhadap pendapatan masyarakat. Usaha kecil menengah (UKM) "Nabil Collection" berdiri pada awal tahun 2000 dengan fokus produksi dan penjualan kemeja dewasa. Di awal merintis usaha, pemilik UKM melakukan sendiri kegiatan produksi kemeja dan kemudian menjual hasil kemejanya secara door to door. Perkembangannya penjualan produk dilakukan secara grosiran dengan menjual di beberapa titik pasar yang ada didaerah Tegal, Cirebon dan sekitarnya. Dua tahun sudah pandemi covid-19 melanda Indonesia khususnya Pekalongan, tentu saja hal ini berimbas pada penurunan tingkat penjualan produk UKM “Nabil Collection”. Sehingga perlu untuk dilakukan literasi aspek pemasaran produk agar pemilik UKM mengetahui bagaimana berdaya saing dimasa pembatasan aktifitas diluar rumah.

Penelitian Silvana, (2012) menjelaskan siklus umur produk batik Danar Hadi dengan strategy marketing mix. Monigir et al., (2016) menunjukkan bahwa pemilihan metode dan media pemasaran secara tepat pada MultiMart di kota Manado terbukti memberikan keunggulan bersaing dan meningkatkan volume penjualan. Pemasaran adalah ujung tombak usaha. Karena jika tidak ada pemasaran maka tidak ada penjualan produk sehingga berdampak pada terganggunya operasional usaha. Pemasaran dimaknai sebagai kegiatan menanamkan dan membangun image produk kepada konsumen agar ketika konsumen membutuhkan maka mereka akan teringat dan membeli produk kita (Daryanto, 2011). Pemasaran adalah usaha untuk meningkatkan penjualan produk, mendapatkan laba dan mempertahankan kelangsungan usaha. Menurut Kotler \& Amstrong, (2012) pemasaran adalah aktifitas interaksi antara satu individu dengan individu yang lain atau antara satu kelompok dengan kelompok yang lain. Menurut Lastianto et al., (2016); Nurseto, (2018); Mardiatmi \& Pinem, (2020) salah satu kegiatan yang dapat meningkatkan kinerja pemasaran adalah promosi.

Interaksi sosial yang terjadi akan menciptakan permintaan dan penawaran produk atau jasa sehingga menciptakan nilai usaha atas produk atau jasa yang ditawarkan ataupun diproduksi oleh pelaku usaha. Dalam pemasaran kita juga perlu memperhatikan kharakteristik produk kita agar disenangi konsumen dari segi fungsi, harga dan kualitas produk. Pelaku UKM juga perlu melakukan segmentasi atau menentukan sasaran pasar dari produk sehingga dapat menyusun strategi pemasaran yang tepat. Strategi pemasaran merupakan upaya atau cara-cara yang dipilih 
untuk mengenalkan, mempromosikan produk kepada pembeli atau konsumen. Kotler \& Amstrong, (2012) menegaskan kembali bahwa strategi pemasaran merupakan implementasi rencana strategi dari kegiatan pemasaran yang melibatkan pemikiran kritis karena tujuan akhirnya adalah menciptakan nilai bagi konsumen dan pelaku usaha secara berkelanjutan. Ada empat strategi pemasaran yang sangat berguna dalam dunia usaha dan insdutry, yaitu pemilihan metode penjualan produk atau jasa dengan mengandalkan getok tular dari mulut ke mulut (word of mouth), pengenalan produk atau jasa kepada konsumen dengan melakukan penawaran dari pintu ke pintu (door to door), melakukan penjualan produk atau jasa dengan aktivitas jemput bola ataupun layanan pesan antar, dan memilih metode penjualan produk atau jasa secara online.

Pemasaran yang dilakukan oleh UKM umumnya adalah pemasaran konvensional dengan system grosiran ataupun eceran dengan strategi pemasaran door to door ataupun pemasaran jemput bola. Perkembangan dunia usaha dan adanya pandemi covid 19 dengan pembatasan aktifitas diluar rumah memaksa para pelaku UKM untuk mengenal strategi pemasaran secara online. Ada banyak manfaat yang dapat diambil dari kegiatan pemasaran online yait media online mampu mengenalkan produk atau jasa area pasar yang lebih luas, pelaku usaha tidak perlu mengeluarkan biaya yang banyak untuk mengenalkan produk atau jasanya, hasil pemasaran produk atau jasa dapat terukur dengan mudah. Akses kemudahan yang diberikan dari metode pemasaran secara online tentu menumbuhkan persaiangan usaha yang ketat. Karena media sosial memberikan informasi yang dapat diakses secara bebas oleh pembeli atau konsumen. Sehingga, pembeli lebih mudah membandingkan antar produk jualan baik dari segi harga dan kualitas antara satu toko dengan toko lainnya. Ada beberapa yang bertanya, tetapi tidak benar-benar jadi membeli. Pelaku UKM perlu memiliki pengetahuan dan ketrampilan yang memadai tentang aspek pemasaran yang meliputi bauran pemasaran dan strategi pemasaran.

\section{MASALAH}

Usaha Kecil Menengah (UKM) “Nabil Collection” mulai beroperasi di tahun 2000 dengan produk kemeja dewasa. Usaha ini merupakan usaha rumahan atau usaha kecil. Pemasaran Kemeja Nabil Collection menggunakan system grosiran (pesanan) dan menjual pada beberapa titik pasar yang ada di daerah tegal, Cirebon dan sekitarnya. Karena itu, pada masa pandemi, pemasaran produknya menjadi terganggu. Penjualan yang turun mengakibatkan aliran uang hasil usaha menurun. Ketrampilan dan pengetahuan yang kurang tentang aspek pemasaran produk membuat pemilik UKM mengalami kesusahan untuk survive dimasa pandemi saat ini.

Produk "Nabil Collection" berupa kemeja dewasa sudah banyak dijual dipasaran, sehingga membutuhkan keunikan dan kekhasan tersendiri dari produk ini. Pemilik usaha sudah melakukan pengemasan produk yang dijual untuk memudahkan konsumen mengenali produk, melakukan variasi warna kemeja dan harga yang terjangkau, system penjualan konvensional secara grosiran dan eceran. Pemilik UKM belum memikirkan pengurusan merk usaha, mencoba menggunakan media pemasaran online. Pemilik UKM membutuhkan literasi aspek pemasaran dari tim pelaksana pengabdian kepada masyarakat untuk keberlangsungan usaha dimasa yang akan datang. 


\section{METODE PELAKSANAAN}

Kegiatan pengabdian kepada masyarakat pada UKM “Nabil Collection" diawali dengan melakukan survey awal ke lokasi UKM untuk memperoleh gambaran permasalahan yang dihadapi UKM ini. Kemudian koordinasi untuk menentukan waktu pelaksanaan literasi sekaligus simulasi dari modul aspek pemasaran sehingga pemilik usaha memperoleh pengetahuan dan ketrampilan yang lebih komprehensif. Metode Pelaksanaan kegiatan pengabdian kepada masyarakat dilakukan melalui tiga tahapan sebagai berikut;

\section{Literasi}

Pemilik UKM "Nabil Collection" diberikan wawasan mengenai aspek pemasaran yang meliputi bauran pemasaran, strategi pemasaran, penentuan segmen sasaran pasar produknya, pengenalan pentingnya merk dagang dan penggunaan sosial media sebagai media pemasaran.
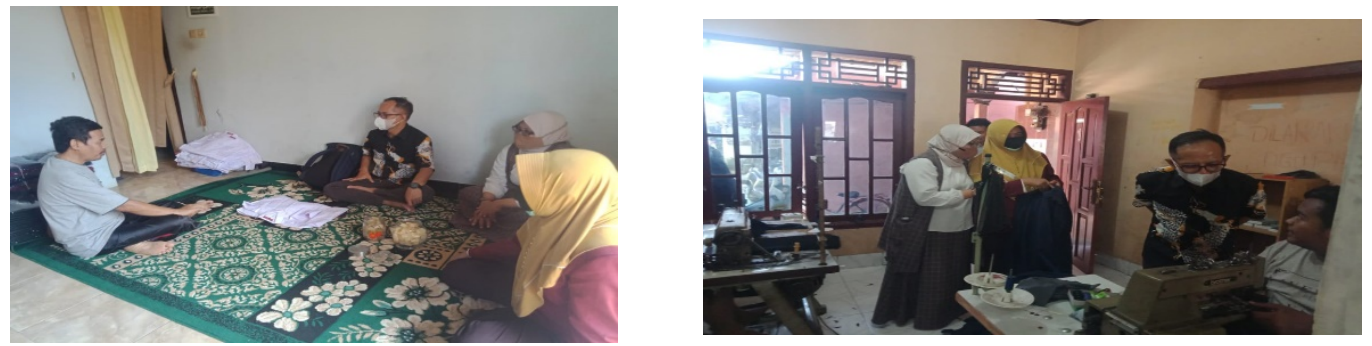

Gambar 1. Pemaparan materi aspek pemasaran produk

\section{Simulasi}

Setelah diberikan pemaparan, pemilik UKM diminta untuk membuat deskripsi mengenai segmen sasaran pasar produk kemeja, penentuan harga produk sehingga terjangkau konsumen dan menggunakan sosial media untuk pemasaran produknya selain melakukan pemasaran secara konvensional.

\section{Diskusi}

Kegiatan kemudian dilanjutkan dengan diskusi antara tim pelaksana pengabdian kepada masyarakat mengenai aspek pemasaran yang mungkin belum dipahami oleh pemilik UKM, seperti mengenai mengapa merk dagang perlu dan manfaatnya apa untuk usaha, kemudian apa manfaat dari melakukan segmen pasar dari produk mereka. Tim pelaksana pengabdian kepada masyarakat memberikan penjelasan secara lebih rinci dan memberikan modul aspek pemasaran kepada pemilik UKM “Nabil Collection”.

\section{HASIL DAN PEMBAHASAN}

\section{Literasi Aspek Pemasaran}

Tim pelaksana kegiatan pengabdian kepada masyarakat menyampaikan cara, metode dan media penjualan produk atau jasa yang dapat dilakukan oleh pemilik usaha "Nabil Collection". Pertama adalah memahamkan definisi dari pemasaran. Tidak dapat dipungkiri, Pemasaran adalah aktivitas atau kegiatan yang harus diperhatikan oleh pelaku UKM dalam menjual produk atau jasanya. Pemasaran merupakan aktifitas yang dilakukan pelaku usaha untuk memberikan 
informasi tentang produk atau jasa yang dibutuhkan oleh konsumen. Pelaku usaha akan mengusahakan menyampaikan produk atau jasa bagi konsumen dengan harga terjangkau, kualitas produk terjaga dan disaat yang tepat. Konsep pemasaran secara konvensional meliputi satu, konsep produksi artinya produk dapat dijumpai dengan mudah oleh konsumen yang membutuhkan, kedua konsep produk artinya konsumen akan memilih produk yang berkualitas, memiliki kegunaan, inovatif dan kreatif. Ketiga, konsep penjualan artinya ada upaya yang agresif untuk melakukan pengenalan produk kepada konsumen melalui promosi. Keempat, konsep pemasaran artinya membuat hubungan yang baik antara konsumen dan produsen seperti melihat kebutuhan konsumen dan menjaga pelayanan konsumen untuk menciptakan loyalitas dan kepuasan pelanggan. Pada bauran pemasaran kita mengenal harga, produk dan tempat. Harga barang terjangkau dan dapat dibeli konsumen. Produk yang disediakan memiliki kegunaan dan cukup berkualitas, jika memungkinkan produk sudah memiliki label berupa merk sehingga mudah dikenali. Tempat untuk melakukan jual beli produk cukup menjangkau konsumen yang membutuhkan. Bauran pemasaran terutama bertujuan untuk meningkatkan loyalitas konsumen (Gugup, 2011).

\section{Simulasi aspek pemasaran yang dilakukan UKM "Nabil Collection.}

Pemilik UKM “Nabil Collection" melakukan pemasaran konvensional dengan menjual produk secara grosir dan eceran pada beberapa titik pasar di Tegal, Cirebon dan sekitarnya. Produk Kemeja yang dihasilkan awalnya hanya kemeja warna putih kemudian dilakukan varian warna kemeja. Produk kemeja juga sudah dilakukan pengemasan dalam plastik sehingga lebih rapi dan tahan lama. Kemeja dilabelling dengan "Nabil Collection" untuk memudahkan konsumen mengenali produknya. Kemeja dijual dengan harga sangat terjangkau yaitu pada harga sekitar Rp. 40.000-Rp. 45.000. Alinegoro et al., (2014) menyatakan merk dagang merupakan brand equity yang dapat menciptakan image produk kepada konsumen. Beberapa Peraturan Perundangundangan tentang merek antara lain:1. Undang Undang Nomor 20 Tahun 2016 Tentang Merek dan Indikasi Geografis; 2. Peraturan Pemerintah Nomor 23 Tahun 1993 Tentang Tata Cara Permohonan Merek; 3. Peraturan Menteri Hukum dan HAM Nomor 67 Tahun 2016 Tentang Pendaftaran Merek. Merk dagang berfungsi sebagai: (1) Pengenal atau penciri yang spesifik dari produk atau jasa; (2) Alat mengenalkan produk atau jasa; (3) Basis membangun image dengan garansi kualitas; (4) Konsumen mudah mengenali produk atau jasa.

Pemilik UKM belum melakukan perhitungan biaya produksi dalam penentuan harga jual produk. Pemilik juga harus lebih fokus pada pemilihan bahan baku kemeja sehingga produknya menjadi lebih berkualitas. Sasaran pasar produk hanya ditentukan untuk kemeja dewasa, belum mengarah pada spesifikasi dari konsumen seperti kemeja ini untuk konsumen usia 25-30 tahun ataukah konsumen usia 30 tahun ke atas ataukah untuk segala usia. Hal ini penting karena kharakteristik konsumen dimasing-masing usia tadi berbeda-beda. Dengan pemahaman yang baik atas selera dan kharakteristik konsumen tadi maka pemilik diharapkan mampu menentukan segmen sasaran produknya. Segmentasi pasar adalah pengelompokkan konsumen sesuai dengan kharakteristik khas konsumen yang memiliki kebutuhan dan selera pasar yang berbeda. Segmentasi pasar memudahkan untuk membuat jalinan hubungan lebih baik antara pelaku UKM 
dengan konsumennya. Langkah selanjutnya adalah memilih strategi pemasaran yang tepat untuk meningkatkan penjualan dan laba usaha. Pada tahap awal, pemilik UKM "Nabil Collection" diminta menyiapkan produk kemeja yang akan dijual. Kemeja tadi difoto, kemudian foto kemeja tersebut didesain dan dideskripsikan terkait detail bahan, warna, ukuran dan harga kemeja. Langkah terakhir adalah kemeja di posting dalam insta story Instagram, Facebook dan Story WA. Menurut Febriyantoro \& Arisandi, (2018) media sosial atau jejaring sosial menjadi platform yang paling sering digunakan oleh masyarakat. Jejaring Pemilik Usaha UKM "Nabil Collection" juga diminta mencoba membuat akun gmail untuk kepentingan pemasaran online ini. Hal ini memberikan kemudahan untuk dapat mengakses Instagram, Facebook ataupun ke media online professional di masa yang akan datang seperti shopee, bukalapak.

\section{Diskusi Aspek Pemasaran yang dilakukan UKM "Nabil Collection"}

Pemilik usaha selama ini melakukan pemasaran tradisional secara grosir dari produknya. Kelebihannya adalah konsumen memperoleh keyakinan dari produk yang dibeli sehingga nanti harapannya bisa menceritakan dan mengajak temannya juga ikut membeli. Biaya pemasaran dengan cara ini juga cenderung lebih murah, karena pemasaran dari "mulut ke mulut" atau getok tular dalam istilah jawa. Namun pemasaran model ini tidak mencakup jangkauan pasar secara lebih luas. Sehingga tim pelaksana pengabdian kepada masyarakat kemudian memberikan pengetahuan tentang pemasaran online. Kim \& Ko, (2012) perilaku positif dari konsumen adalah imbas dari respon atas pemasaran produk atau jasa melalui sosial media.

Kemajuan teknologi dan bisnis serta dampak dari pandemi covid-19 membuat banyak UKM mengalami penurunan penjualan. Kondisi UKM banyak yang terpaksa menghentikan kegiatan produksi ataupun menutup sementara tokonya, Sebagian lainnya merumahkan tenaga kerja untuk waktu yang belum bisa ditentukan. Sehingga untuk meningkatkan penjualan produk maka UKM perlu melakukan adaptasi pemasaran secara online. Menurut Mangolda \& Faulds, (2009) Bauran Pemasaran dapat diimplementasikan dari tindakan komunikasi merk barang atau jasa dengan pemasaran melalui media sosial (social media marketing). Media pemasaran dengan menggunakan kemajuan teknologi yang mudah adalah pemasaran berbasis sosial media seperti facebook, story whatsapp ataupun instagram. Pemasaran online berbasis sosial media karena pengguna sosial media cukup besar di Indonesia. Literatur secara umum mencatat ada sekitar 170 juta penduduk di Indonesi merupakan pengguna aktif media sosial atau 61,8 persen dari total populasi pada Januari 2021. Angka ini juga meningkat 10 juta, atau sekitar 6,3 persen dibandingkan tahun lalu. Kementerian Komunikasi dan Informatika (Kemenkominfo) tahun 2021 menegaskan ada sekitar 63 juta orang dari total penduduk Indonesia merupakan pengguna internet (Kominfo, 2021). Enam puluh tiga juta dari pengguna internet aktif ada hampir Sembilan puluh lima persen melakukan aktifitas akses jejaring sosial. Secara umum, Pelaku UKM membuat akun gmail dan kemudian pelaku UKM cukup melakukan posting produknya disertai dengan deskripsi produk. Beberapa hal yang perlu di perhatikan oleh UKM dalam pemasaran online adalah membuat konten produk yang menarik, deskripsi dari produk harus jelas dan rinci, produk di up-date setiap hari dan fast respons terhadap order dari konsumen. Pemasaran online juga dapat memberikan penawaran diskon untuk menarik minat konsumen atau pembeli. 
Pemasaran online dari produk kemeja "Nabil Collection" membutuhkan pemahaman komprehensif dari pemiliknya dan kesungguhan dalam penerapannya. Pemasaran online akan mendorong peningkatan penjualan. Karena pemasaran online menjadikan jangkauan pasar produk lebih luas sehingga perkembangan usaha menjadi lebih cepat. Tim pelaksana pengabdian kepada masyarakat memberikan modul aspek pemasaran yang berisi tentang bauran pemasaran, kemasan produk, merk dagang dan manfaat ekonomisnya dan strategi pemasaran kepada pemilik UKM “Nabil Collection". Harapannya pemilik UKM akan dapat membaca secara berulang sehingga memperoleh pemahaman yang baik tentang aspek pemasaran produk.

\section{KESIMPULAN}

Usaha Kemeja Dewasa "Nabil Collection" merupakan UKM yang melakukan produksi, pengemasan dan penjualan produknya kepada konsumen atau pembeli. Penjualan produk kemeja dewasa "Nabil Collection" mengalami penurunan selama dua tahun terakhir. Kegiatan pengabdian kepada masyarakat dilakukan untuk memberikan literasi berupa peningkatan pengetahuan dan ketrampilan kepada pemilik UKM “Nabil Collection” tentang aspek pemasaran produk. Sehingga UKM ini mampu memiliki daya saing dan menjaga keberlangsungan hidup usahanya terutama dimasa pembatasan aktifitas diluar rumah akibat pandemi.

\section{UCAPAN TERIMA KASIH}

Kegiatan pengabdian kepada masyarakat yang dilakukan memperoleh pendanaan dari LPPM Universitas Pekalongan. Ucapan terima kasih kepada Lembaga penelitian dan pengabdian kepada masyarakat (LPPM) Universitas Pekalongan dari tim pelaksana pengabdian kepada masyarakat. Semoga kegiatan ini memberikan manfaat kepada UKM “Nabil Collection" untuk dapat survive usaha dan berdaya saing dimasa pendemi covid-19.

\section{DAFTAR PUSTAKA}

Alinegoro, I. H., Naibaho, H., \& Oliandes, S. (2014). Pengaruh Elemen Ekuitas Merek (Brand Equity) terhadap Keputusan Pembelian Produk Pakaian (X) S.M.L di Surabaya. Jurnal GEMA AKTUALITA, 3(1), 32-43.

BPS. (2020). Pekalongan dalam angka tahun 2020. BPSkotaPekalongan.go.id.

Darwanto. (2013). Peningkatan Daya Saing UMKM Berbasis Inovasi dan Kreativitas (Strategi Penguatan Property Right Terhadap Inovasi Dan Kreativitas). Jurnal Bisnis Dan Ekonomi (JBE), 20(2), 142-149.

Daryanto. (2011). Sari Kuliah Manajemen Pemasaran. PT Sarana Tutorial Nurani Sejahtera.

Febriyantoro, M. T., \& Arisandi, D. (2018). Pemanfaatan Digital Marketing Bagi Usaha Mikro, Kecil Dan Menengah Pada Era Masyarakat Ekonomi Asean. JMD: Jurnal Riset Manajemen \& Bisnis Dewantara, 1(2), 61-76. https://doi.org/10.26533/jmd.v1i2.175

Gugup, K. (2011). Bisnis Pengantar. BPFE.

Kim, A. J., \& Ko, E. (2012). Do social media marketing activities enhance customer equity? An empirical study of luxury fashion brand. Journal of Business Research, 65(10), 1480-1486. https://doi.org/10.1016/j.jbusres.2011.10.014 
Kominfo. (2021). Pengguna internet di Indonesia sebanyak 63 Juta orang. https://kominfo.go.id/content/detail/3415/kominfo-pengguna-internet-di-indonesia-63-jutaorang/0/berita_satker

Kotler, P., \& Amstrong, G. (2012). Prinsip-Prinsip Manajemen Pemasaran. In Edisi 13 Jilid 1. Erlangga.

Lastianto, A., Pradhanawati, A., \& Widiartanto. (2016). Pengaruh Promosi, intensitas persaingan dan kebijakan produk terhadap kinerja pemasaran Bandeng Presto pada sentra Usaha Bandeng Presto Kelurahan Tambakrejo Semarang. Ilmu Administrasi Bisnis, 1-7.

Mangolda, W. G., \& Faulds, D. J. (2009). No TitleSocial media: The new hybrid element of the promotion mix. Business Horizons, 52(4), 357-365. https://doi.org/10.1016/j.bushor.2009.03.002

Mardiatmi, A. B. D., \& Pinem, D. (2020). Literasi promotional mix pada UKM-UKM di kota Depok, Jawa Barat. Yumary: Jurnal Pengabdian Kepada Masyarakat, 1(2), 89-98. https://doi.org/10.35912/jpm.v1i2.89

Monigir, L., Mandey, S. L., \& W., O. I. (2016). Penerapan Strategi Pemasaran Untuk Mencapai Keunggulan Bersaing (Studi Kasus Pada Multi Mart Ranotana Manado). Jurnal Emba: Jurnal Riset Ekonomi, Manajemen, Bisnis Dan Akuntansi, 4(4). https://doi.org/10.35794/emba.4.4.2016.14533

Nurseto, S. (2018). Pengaruh saluran distribusi dan promosi terhadap kinerja pemasaran (Studi Kasus pada UKM furniture Kota Semarang). Jurnal Administrasi Bisnis, 7(2), 103. https://doi.org/10.14710/jab.v7i2.22695

Silvana. (2012). Penerapan Strategi Pemasaran Marketing Mix (Studi Kasus pada PT. Batik Danar Hadi). Jurnal Ilmiah Widya Teknika, 20(1), 55-62. https://doi.org/10.31328/jwt.v20i1.8 